\title{
Reflections on Neoliberal Policy: A Critical Insight into Recent Development Practices in Egypt and Morocco
}

\author{
Alex Afouxenidis' ${ }^{1}$, Christos Kourtelis ${ }^{2}$ \\ ${ }^{1}$ Institute of Social Research, National Centre for Social Research, Athens, Greece \\ ${ }^{2}$ Department of Political Science, Antalya International University, Antalya, Turkey \\ Email: afouxenidis@ekke.gr
}

How to cite this paper: Afouxenidis, A., \& Kourtelis, C. (2017). Reflections on Neoliberal Policy: A Critical Insight into Recent Development Practices in Egypt and Morocco. Open Journal of Political Science, 7 , 291-310.

https://doi.org/10.4236/ojps.2017.72024

Received: February 22, 2017

Accepted: April 23, 2017

Published: April 26, 2017

Copyright $\odot 2017$ by authors and Scientific Research Publishing Inc. This work is licensed under the Creative Commons Attribution International License (CC BY 4.0). http://creativecommons.org/licenses/by/4.0/

\begin{abstract}
For a number of years, western states and international institutions provided financial assistance to the developing countries and promoted solutions to political inequality based on two main principles. The first was related to the notion of economic liberalization, which would unfold the potentials of the market and minimize the role of the state in the economic sphere. The second was that western support to the embryonic civil societies of the developing world would give voice to the populations of these countries and would change the nature of authoritative political regimes. These ideas continue to inform the debate about the development of north African countries. This paper presents and analyzes two nations in north Africa, Egypt and Morocco, in terms of how they exploited the global economic situation and whether they benefited from the openness of the markets. Reference is made to the fact that some political freedoms were initiated in those countries, but they were not democratized. Therefore, the paper critically examines and distinguishes the notion of economic liberalization from the idea of democratization by exploring the ways regimes handled fundamental notions of political equality.
\end{abstract}

\section{Keywords}

Economic Liberalization, Democratization, Development, Political Equality

\section{Introduction}

Fukuyama (1992), argued that liberal democracy will be the final form of human government on a universal scale. This particular argument was supported by many academics and politicians especially in relation to the connection between economic (neo) liberalism and democratization. During the past thirty years or 
so, especially after the fall of eastern bloc regimes and their subsequent incorporation into the world economic system, there was a brief moment of optimism about the future. The basic idea was related to the principle that slowly but surely global society is moving away from totalitarianism and that with help provided by the people (civil society), political and civic participation will increase and therefore democracy will be enriched.

However, global society is undergoing a period of profound economic crisis and transition, and reality has proved that the above perspective is wrong. Global society and economy moved into, more or less, the opposite direction. There were indeed massive efforts and actions by civic groups ranging from local initiatives to regional and global protests. New movements and organizations appeared which voiced their concerns and put forward their policies on a number of issues such as combating poverty and caring for the environment. But the fundamentals of humanity such as poverty, social inequality, human rights and justice returned with a vengeance. Instead of people increasing their participation in forming and implementing policies, they have been increasingly excluded from the political process resulting in a general diminution of civil rights on a global scale. David Harvey's seminal idea on "accumulation by dispossession” in which he explains the economic aspect of what he calls the 'new' imperialism is closely linked to this.

Subsequently, what sort of "mass society" politics are we experiencing today? It can be safely said that "politics" and the political process in general, have been transformed: "governance" and "top-down" agenda setting is the name of the game in local and global spaces. Essentially liberal-democratic regimes have been de-politicized and although traditional political rights remain in place (for example voting rights), other civil rights which enhance public dialogue and bring coherence to the public sphere have been gradually diminishing (such as education or work). These are indeed uncertain times and the ways in which civil associations and democratic institutions will respond shall be indicative of future developments.

This paper attempts to show that the liberalization of the markets does not necessarily allow new actors to emerge and alter the decision-making process, which is dominated by authoritarian regimes. The examples of Egypt and Morocco show that democratization and political inequalities have increased during the implementation of neoliberal reforms. The paper analyses the political and economic landscape in the two North African countries until 2012. It shows how the governments of the two countries managed to manipulate the global political economy for their benefit and how these policies allowed extremist groups to gain power (especially in Egypt). In the second part it examines the pressures that Western powers exercised to North African countries for neoliberal reforms and the related agreements that promoted the liberalization of EU-North African trade. The third and fourth parts demonstrate how these agreements were manipulated by the local elites and failed to promote the sustainable and inclusive growth of the two countries. Finally the conclusion summarizes the findings 
of the paper.

\section{A Theoretical Perspective}

In his recent work, Erik Olin Wright correctly identifies reforms taken by conservatives to have had "... massive, destructive unintended consequences. The havoc created in many poor countries by World Bank structural adjustment programs would be an example. And ... conservatives themselves argue for radical, society-wide projects of institutional design, as in the catastrophic shocktherapy strategy for transforming the command economy of the Soviet Union into free market capitalism in the 1990s" (Wright, 2010).

A similar picture can be depicted in many other examples around the globe, and indeed recently in Greece with the instigation of "structural reforms" which essentially worsened economic performance and more importantly limited democratic procedures and widened social inequality indicators (Grimson \& Kessler, 2005). In Greece, political hegemony coupled by liberalization, had, in our view, two immediate practical impacts. Firstly, social inequality and by default social injustice, grew. The economic system run in opposition to democratic forms of inclusion fragmenting and diminishing demands by a variety of social groups. In simple terms, the marginalized and discriminated groups were further weakened as a result. Secondly, and perhaps this is more important, by privatizing large sectors of the economy, major principles of public policy such as those, for example, which relate to the concept of public service were weakened or even abandoned. Thus, the debate on democracy (and accountability), and of methods to reduce social inequality in conjuncture with the functioning of these sectors was/is depoliticized: the practical effects of this process have become matters of discussion amongst technical experts, i.e. those groups who have set the political and economic agenda in the first place (Afouxenidis, 2012).

The above thoughts form the main thrust of our argument. The neo-liberal model finds itself at a critical juncture since its core principle, namely that economic freedom empowers individuals and therefore enhances democracy, is faltering. A quick review of relevant data shows that social inequality indicators are higher in fully liberalized economies such as the USA and Britain (Rapley, 2004), but this does not materialize in major shifts in policy orientations. In our opinion this is mainly due to the fact that 'social inequality' is a multi-factorial concept (as opposed to poverty, for example) which necessarily involves questions and issues of power and authority relations at the institutional, political and economic level. Inequality, in general, as a concept appears during late modernity and as a field it has been taken over by specific groups of economists and/or empirical sociologists. Political sociologists have not, until recently, had much to say about this especially in connection to fundamental notions such as power or social transformation. The end result has been that not much work has been done connecting the triangle between democracy - liberalization and social inequality. Most of the research agenda has been mainly directed towards issues such as poverty and the management of poor or excluded populations, a rela- 
tively less politically sensitive topic. It is interesting to note that comparative evidence on social inequality is still difficult to find.

In addition to the above, political discussion around this issue is almost non-existent. An agenda on social inequality which would incorporate political questions would have to incorporate and bring together a number of topics which are now separately discussed, such as:

- Internal and external inequality, amongst and between nation-states in relation to questions of power

- The effect of the above on political decision-making

- The role of international agents

- Case studies of particular countries and particular forms of social inequality

- The role politicians and civil society agents play in shaping some or all of the above.

Another element which involves the framing of the various political agendas, is constituted by the shift in the dominant ideological forms since the 1980s. Social inequality was transformed from a major issue which had to do with the inner workings of liberal capitalism, to a matter which is more closely connected to things like "under-development", "poor social policy" or even, a matter which has to do with self-help and volunteer work. Neo liberals utilized the above idea to argue that, for example, in corrupt regimes where social inequality is high, what we need is more structural reform and free market policies which at some point will play a positive role in society at large. This is a substantial shift in basic liberal ideology which moved from the general idea of a just organization of society, towards the ideological imagination, that the market will do that instead of government. In other words, the fundamental idea of gradual social and economic convergence (and/or integration) has been substituted by the political notion of divergence.

The general theoretical (and empirical) question which immediately comes to mind is the following: why have political systems and societies across the globe shifted from the paradigm of embedded liberalism to that of the Washington Consensus? This question is up for grabs right now since there is no particular answer to it. On a theoretical and practical political level, the neo-liberal project is rather dysfunctional, since it has not delivered what it promised, but it remains very strong and successful on the ideological and cultural domains. The rest of this paper empirically examines the above few arguments with respect to the changes that have occurred in Morocco and Egypt.

\section{Setting the Agenda: Egypt and Morocco}

In the 1960s and 1970s Morocco and Egypt followed development strategies attempting to protect domestic markets by focusing primarily on import-substituting industrialization and agricultural self-efficiency. In this sense, trade and industrial policies were based on high tariffs and on restrictions in imports. The inefficiencies and the distortions of these inward-looking strategies were exacerbated by the macroeconomic difficulties of the late 1970s and 1980s leading 
the two countries to the IMF and to Structural Adjustment Programs (SAPs). Morocco started to implement the first SAPs in the mid-1980s, whereas Egypt joined the ride a few years later, in 1991. The beginning of the 1990s was an era of cataclysmic changes of a global scale, which could not leave the region unaffected. The collapse of eastern European countries and the end of the Cold War were followed by the creation of the EU (with the sign of the Maastricht Treaty in 1993) and by the development of a new European strategy towards the Arab Mediterranean partners; the Barcelona Process, which was signed in 1995.

The logic behind the creation of the EU was "exported" to the Arab Mediterranean countries, through the Barcelona Process and after the Easter Enlargement through the European Neighborhood Policy (ENP). Even if the EU institutions rejected the idea of making any of these countries members of the EU, Europe, as the largest trade partner of these countries, saw the creation of a free market area (by 2010) as the main way to develop and stabilize the Arab neighbors. Although the EU protected some "sensitive" agricultural products (and its labor market) from the Arab competition, the Association Agreements and the Action Plans signed with these countries were perceived as cornerstones of the further reforms that the Arab states needed to do in order to 'capture' the train of globalization. These reforms continued the work of the previous SAPs, in other words they attempted to make the region more competitive in the global market by minimizing the role of the state in the economy, in order to attract more FDIs and to fight unemployment and poverty.

However, the neoliberal logic of the international organizations that imposed such reforms to the Arab countries was not merely economic. It relied on a Marxist understanding about the relations between the state and the economy, which underlined the impact of changes in the infrastructure on the political system (Dillman, 2002). Under this notion, more economic openness of these countries would yield to more democratic reforms.

Some signs of sporadic political changes were observed since the implementation of these reforms. In Morocco, King Hassan II implemented some limited reforms and his son Muhammad VI respected the human rights more than his father. In Egypt, Mubarak has opened slightly the political sphere to other actors. For example, several small NGOs were created as an attempt of the government to show that it is keen to create a strong civil society.

This limited political liberalization was perceived in different ways by the academia and the policymakers. Taking examples from Huntington's work Political Order in Changing Societies (1968) many commentators noticed that the Arab regimes, especially the monarchies of the region, were facing the "King's dilemma". In other words, the rulers of these countries were forced to limit their powers due to the relentless character of modernization. The reforms that the rulers imposed yielded to more social demands and these monarchies would eventually be transformed in constitutional monarchies. Other analysts and policy makers of international organizations saw these developments as signs of gradual democratization. In this sense, gradualism indicated a natural and linear 
passage from political liberalization to democracy for both the monarchies and the republics of the broader region.

The gradualist scenario was mostly advocated by policy makers of international organizations. This happened for reasons, which are related to the international character of the regimes. A gradualist notion of democracy guaranteed that the successors of these governments would be cooperative and predictable. This issue is not related only to the continuity of the economic and historic ties that the Western powers share with the countries of North Africa but also to the security of the Western powers. The Islamist threat that started with the civil war in Algeria and continued with the terrorist attacks in the US and in Europe put the security of the EU and of the US very high on their agenda. Under this notion, a gradual move towards democracy would give time to these regimes to minimize the extremist alternatives and would guarantee both the stability and the democratic transformation of the region. How can someone buy time under the gradualist scenario? Here, successful gradual transformation relies on the economic changes of the region. Privatization of key sectors of the economy would develop an independent business sector with stronger political voice. Simultaneously, the success of these reforms would minimize the extremist alternatives. Hence, the economic changes would not only foster growth, but they would create new political coalitions and preferences, which in turn result to more democratic institutions.

Yet, what is happening over the last two decades is that so far we are witnessing a continuous economic liberalization of the North African economies without significant democratization. Under the light of the Arab Spring, which for many (especially for the media) signifies a paradigmatic shift, two questions emerge. What has gone wrong with the neoliberal hypothesis about the democratization of North Africa and why the results of the Arab Spring did not affect the North African countries in the same way?

Different reasons have been given to illustrate what has gone wrong with this logic and why Egypt and Morocco followed different trajectories. Since the beginning of the Barcelona Process, which was the first comprehensive strategy of the EU towards its Southern neighbors, the related bibliography compartmentalized the strategy in order to analyze it in greater depth. Yet, these explanations are individually inefficient to address the aforementioned questions. The problem in this case is that by isolating the different aspects of these 'grant' strategies, such as immigration issues, economic parameters, civil society problems the authors focused on the efficiency or the inefficiency of the several tools of the policy (Bensaad, 2007; Bilgin, 2009; Bodenstein \& Furness, 2009; Comelli \& Paciello, 2007; Emerson, Noutcheva, \& Popescu, 2007; Holm, 2008; Zaiotti, 2007). Under this notion, the efficiency of the strategy relied on a different independent variable, which is the stability of the system. This eternal stability of the system was highlighted in an interview with an EU official (before the events in Tunisia) who claimed that the EC knew the successors of these regimes for the next 30 years. For the EC, these would be the descendants of the existing rulers. Similar- 
ly, a few months before the Arab Spring a prominent academic from North Africa, at a conference at KCL, was asking the Western powers to push for more democratization, because the domestic environment of the North African countries will never allow deep democratic changes. After the events of the Arab Spring the crucial issue is to see what fed the minds of the technocrats in Brussels and the arguments of several academics. Thus, in order to fully understand the conjunction between economic liberalization and political liberalization, we need to address the economic and political responses of the North African states to the international pressures for reforms.

A first attempt to theorize this conjunction was provided by the "rentier states" model. According to Mideast scholars, the rents (especially from oil) that the states of Middle East gain have undemocratic effects for three reasons (Ross, 2001). First, these states use low taxation to compensate for low representation and accountability. Second, they use the oil profits to create strong security forces. Third, such growth on oil and minerals does not allow the democratic domestic social forces to emerge, because very few are engaged in the generation of the wealth and the majority is related to the distribution and utilization of the sources (Beblawi, 1990). Hence, this distribution of labor creates strong systems of patronage.

However, this theoretical model can only partially explain the situation in North Africa. Morocco and Tunisia cannot be considered as rentier states, even if the former exports large amounts of phosphate. Egypt has oil, gas and exploits the Suez Canal, yet the situation differs from that of the Gulf states. Indeed, the country has invested a lot of money to the strength of the security forces and all the three have strong systems of patronage. Yet, there are large sectors of their economies, which do not depend on these sources, meaning that the rents that these states gain are not enough to prevent group formations that demand changes.

So, how did these states try to control these groups? What have they accomplished and how successful have they been so far to manage the expectations of a more educated growing population and the pressures of the western actors for freer trade? Regarding the latter question, the pressures from the EU and the US led the countries of North Africa to sign agreements for the liberalization of their markets. As said above, the benchmark towards this end was the Barcelona Process, which planned to create a free trade Mediterranean area by 2010 . However, even before its ratification, econometric analyses projected that the outcomes of freer trade between Morocco, Egypt and the EU would not bring significant results for the two North African countries. For Morocco, only when agricultural free trade is established, free trade with the EU will result to $1.5 \%$ GDP growth (Jaidi, 1994). In this case, the agricultural and phosphate sectors lead the economic growth of the country. However, if someone sees the consequences on the entire Moroccan industry, then the results are different. Only $40 \%$ of the Moroccan industry can compete under a free trade regime and these sectors are related to the production of phosphoric acid, of fertilizers, of some 
food products and of electronic equipment. $20 \%$ of the country's industries need aid to upgrade in order to survive (clothing and leather industries) and the remaining 40\% cannot compete the European companies (Jaidi, 1994; White, 2001). For example, the European dairy and chemical products will come in much better prices and drive the Moroccan producers out of the market.

The Egyptian economy is in a slightly different situation. The fiscal impact of free trade would be smaller, since the country can rely on the revenues from the Suez Canal and on the oil and gas incomes to compensate the lost tariff revenues. Under this condition, it is ironic to see Morocco to engage deeper into the ENP free trade agreements and pioneer the process and not Egypt. Yet, even in the Egyptian case trade integration seems to bring negative results to the country (Talani, 2009).

Even if it is clear that deeper integration into the global markets under a free trade regime has significant costs for both countries, there are some studies that mention the dynamic benefits of this strategy (Achy \& Sekkat, 2010; Jelili \& Goaied, 2010). The promotion of regional trade can highlight the comparative advantages of the partner countries and these studies focus more on the dynamic benefits of free trade, which are indirect. Such benefits include technology transfer, increase in overall production and more efficient allocation of resources. Yet, even some of these studies acknowledge that the results are not obvious in the short run and they follow a lengthy painful adjustment period, which involves the increase of unemployment and of poverty. For example, in Morocco, in spite of a severe structural adjustment programme that made labour cheaper and the business environment friendlier to foreign investments, FDIs proved volatile and they were related to the large scale privatizations of state companies (Fontagné \& Péridy, 1997). The funds from these privatizations have gone to the state elites, which used them to maintain their political and economic power, not to tackle poverty and inequality. The following Tables 1-7 illustrate the poor results from the openness of the North African markets towards poverty and inequality.

The above illustrate a mixed picture in the two countries. A quick look in these Table 8, Table 9 shows that Morocco is in a better position than Egypt and

Table 1. Share of poorest quintile in national consumption or income $\%$ 2010-2011.

\begin{tabular}{cc}
\hline Egypt & $9.2 \%$ \\
Morocco & $6.5 \%$ \\
\hline
\end{tabular}

Source: IBRD/WB.

Table 2. Vulnerable employment: Unpaid family workers and own-account workers \% of total employment.

\begin{tabular}{rcc}
\hline & 1990 & $2007-2010$ \\
\hline Egypt & $28 \%$ & $27 \%$ \\
Morocco & $\mathrm{n} / \mathrm{a}$ & $51 \%$ \\
\hline
\end{tabular}

Source: IBRD/WB. 
Table 3. Unemployment of total labor force.

\begin{tabular}{ccc}
\hline & $1990-1992$ & $2007-2012$ \\
\hline Egypt & $9 \%$ & $9.4 \%$ \\
Morocco & $16 \%$ & $10 \%$ \\
\hline
\end{tabular}

Source: IBRD/WB.

Table 4. Population below national poverty line.

\begin{tabular}{cccccccc}
\hline & Rural & Urban & National & & Rural & Urban & National \\
\hline Egypt (2005) & $26.8 \%$ & $10.1 \%$ & $19.6 \%$ & 2008 & $30 \%$ & $10.6 \%$ & $22 \%$ \\
Morocco (2001) & $25.1 \%$ & $7.6 \%$ & $15.3 \%$ & 2007 & $14.5 \%$ & $4.8 \%$ & $9 \%$ \\
\hline
\end{tabular}

Source: IBRD/WB.

Table 5. Gini Coefficient (0 perfect equality, 100 perfect inequality).

\begin{tabular}{cc}
\hline Egypt (2008) & $30.8 \%$ \\
Morocco (2007) & $40.9 \%$ \\
France (1995) & $32.7 \%$ \\
Germany (2000) & $28.3 \%$ \\
UK (1999) & $36 \%$ \\
USA (2000) & $40.8 \%$ \\
Greece (2000) & $34.3 \%$ \\
\hline
\end{tabular}

Source: IBRD/WB.

Table 6. Youth unemployment: Male \% of male labour force age 15 - 24 (2007-2010).

\begin{tabular}{cc}
\hline Egypt & $17 \%$ \\
Morocco & $23 \%$ \\
\hline
\end{tabular}

Source: IBRD/WB.

Table 7. Youth unemployment: Female \% of female labour force age 15 - 24 (2007-2010).

\begin{tabular}{cc}
\hline Egypt & $48 \%$ \\
Morocco & $19 \%$ \\
\hline
\end{tabular}

Source: IBRD/WB.

Table 8. Country trade structure by partner. Exports (\%) by main region of destination.

\begin{tabular}{ccc}
\hline Origin & Year & Destination: EU \\
\hline Egypt & $1995-2005-2009$ & $48.1-34.1-29.4$ \\
Morocco & $1995-2005-2009$ & $59.9-69.0-61.9$ \\
\hline
\end{tabular}

Source: UNCTAD. 
Table 9. Country trade structure by partner. Imports (\%) by main region of origin.

\begin{tabular}{ccccc}
\hline Country & Year & Origin: EU & Origin: USA & $\begin{array}{c}\text { Total imports of } \\
\text { developed economies }\end{array}$ \\
\hline Egypt & $1995-2005-2009$ & $41.9-24.0-31.7$ & $18.8-8.9-10.6$ & $68.3-38.9-48.9$ \\
Morocco & $1995-2005-2009$ & $53.0-50.8-58.2$ & $5.9-3.4-5.6$ & $63.4-58.5-67.2$ \\
\hline
\end{tabular}

Source: UNCSTAD.

the proponents of neo-liberalism say that this is an outcome of the deeper structural reforms that the country did than these of Egypt. Yet, the answer is not that straightforward. The poorest quintile contributes only $6.5 \%$ in the national consumption, meaning that these people are totally marginalized and the vulnerable unemployment touches more than the half of the working population. Male youth unemployment is above $20 \%$ and the last two decades of neoliberal reforms have not reduced inequality. According to the Gini coefficient, Morocco is more unequal than Egypt, the percentage being above 40\% (IBRD/WB, 2012).

In Egypt, vulnerable employment has not changed after two decades of reforms and actually unemployment has increased. Regarding the youth, the economy of the country manages to employ more young men than Morocco, but youth unemployment is more obvious among women. Almost half of the young women of the country are without a job. The worst issue is related to the people that are below the poverty line. Between 2005 and 2008 the amount of people below the poverty line, in both rural and urban areas increased.

Subsequently, the fact that the governments of the North African countries have signed free trade agreements, despite empirical research that the costs of these are high, shows that the North African governments pursued an agenda, which is not based on a broad consensus. This position proves that they believed that they were immune from any political consequences and prepared for the transitional socio-economic unrest. This sort of immunity highlights the fact that the North African states control in a large extent the various actors of the local economies. In fact, the dominance of the state over the local economy and on the various groups is constantly mentioned in the relevant bibliography (Bellin, 2002; Paczynska, 2009; White, 2001). Yet, even if the Arab Mediterranean states control the local economies, state-dominance does not tell us something about the groups that are actually benefited from the openness of the North African markets. However, for the citizens of North Africa the answer is probably obvious. It is the 'local elites' that benefit from the openness of the North African economies. Yet, which are these 'local elites' what are their relations with the North African states and what do they pursue from the this neoliberal strategies? Simplifying the seminal explanation given by Prebisch about the elites of the peripheral countries of Latin America (Prebisch, 1950), for the average North African citizen, these elites probably reflect these wealthy upper class citizens, who imitate the Western culture and have a close relationship with the state seeking protection and patronage. In addition, these elites usually carry the names of certain families and this phenomenon illustrates the extent of wealth 
that a small number of families have in their hands. Nevertheless, this explanation does not reveal much about the gains of these elites from the openness of the two countries in the global markets. So, to understand their function in a greater extent, here they are distinguished in two types: the state elite and the business elite.

\section{State Elites in Egypt and Morocco}

Do the political elites gain from the liberalization of trade and from the agreements that have signed with the Western powers? And if they are benefited, how do they manage to do so? By paraphrasing the functionalist logic of the EU experience, someone could argue that trade liberalization can create spill over political effects that will lead to the democratization of the partner countries and to the change of their political systems. Indeed, some changes have occurred to these systems and the trade benefits with Europe were the driving forces behind these reforms. For example, to facilitate trade with the EU in the 1980s, the Egyptian government created a mix of parastatals and state controlled agencies. In Morocco, the king followed a different pathway to improve its trade relations with the EU. In Morocco, the state did not create so many parastatals, but more investment agencies, which were devoted to external trade relations.

Nonetheless, regardless the form of the relevant institutions, the purpose of these agencies and parastatals is similar in the North African countries. The first is to develop the relations of the North African countries with external actors and to facilitate trade predominately with the EU. The second is to strengthen the state control over external trade, to keep the state unaccountable and out of any public control. In that respect, in Egypt, Mubarak resisted to any significant reforms that could change the structure of the state. In Morocco, Mohammad VI is perceived as a moderate and reformist ruler. He replaced his Minister of Interior, who had a security background with technocrats in order to spur economic growth and he gave some rights to women. Yet, the state apparatus is far away from being described as a merit-based mechanism and as stated before the state retains the control of the local economy.

The EU tools and financial aid (the EU is the biggest trade partner of the two countries) have not done much to alter this situation. The EU provides technical assistance and money to modernize the state mechanisms, but these tools have a minimal impact on the structure of the state. For example, according to the EC, the ENPI's (European Neighborhood Policy Instrument) Twinning projects bring together public sector expertise from EU member states and from the partner countries with the aim of modernize the state's institutions. TAIEX (Technical assistance and information exchange) is an institution building project, which helps the partners to harmonize their rules with the EU legislation. SIGMA (Support for Improvement in Governance and Management) is a joined initiative of the OECD and the EU and it focuses on administrative reforms by improving the partners' public sector ethics.

Judging from the experience of the East European states that have used these 
tools, someone can see that they cannot transform the North African states. Twinning program pays the civil servants of the EU member states to work with the ministries of the partner countries. However, they do not focus on institutional models, but on technical issues and to standardize harmonization. Moreover, as the European civil servants come from the Member states, they are not controlled centrally from the EC and they communicate the principles of their countries. Thus, any sort of institutional transformation appears as random and abstract, depending on the experience of the European civil servant (Grabbe, 2003). In the same vein, TAIEX is a short-term tool that basically identifies future Twinning projects and educates the civil servants of the partner countries about the EU acquis, so the main aim of this tool is not to reform the state mechanisms.

SIGMA, which is meant to support administrative reforms, only provides baseline guidance to the partner countries. In addition, given the fact that the South partner countries do not have the option of becoming member states, the political elites do not have the incentive of changing the function of the state mechanisms. On the contrary, the ENPI tools are perceived from the political elites as instruments of maintaining their control over key sectors of the economy, by facilitating political reforms which cannot put at risk their power. The inability of these instruments to change fundamentally the political situation of the partner countries is acknowledged by officials that work for the EC. Clearly, as one stated, 'we cannot change the function of the political elites if they don't want to change. It is impossible' (Personal interview 21/01/2011). Actually, the ENP reports for the two countries clearly state that the political reforms in the partner countries are far behind from the economic reforms that they have implemented.

\section{Identifying the Business Elite of North African Countries}

The business elite in the North African countries derives from the great bourgeois families and it is determined by family ties (Dawson, 2009). This means that the control remains in the hands of the family and that external participation is not substantial. The primary aim of the company is to reproduce family wealth, without compromising any family assets to external control (Dawson, 2009). When external participation is perceived as necessary, this is introduced (most times) as technical assistance, nor as co ownership.

The power of family ties is reflected in the structure of the business associations. In many cases, these associations merely promote and mirror the family networks of specific sectors. For example, the food and soap associations in Morocco are as many as the families that control the relevant markets and each one of them represents the broader family network (Benhaddou, 1997). As a result of this disunity, the interests of the business elites are often narrowly defined and their negotiating power is fragmented. This situation gives more space to the political elites. Disputes that could be solved in a more unified environment are often a subject of arbitration, a situation that allows the state to control the eco- 
nomic actors. Also, in that way, the role of the political elites is perceived by the business elites as necessary, an element that increases the political power of the former.

The dependence of the business elites from their political patrons is more obvious when the matter of the debate is international trade. In this situation, businesses are often sought to seek more protection from the state, rather than support for their modernization (Tangeaoui, 1993). This search for protection is an outcome of their inability to compete with the European companies. However, at this point Tangeaoui's explanation is very general to explain who wins and who loses from the openness of the North African markets. In order to answer this answer more specifically, it is necessary to see each sector separately and categorize the businesses in two types. Export oriented industries and inward looking businesses.

Regarding to the agricultural sector the strategies of the North African countries are different, and this change is related to their size and their exposition to the EU market. In 2009, only $29.4 \%$ of the Egyptian exports were sent to the EU. Europe was the final destination of almost $62 \%$ of the Moroccan exports. Similarly, $31.8 \%$ and $59 \%$ of the Egyptian and Moroccan imports are exported from the EU. Yet, it must be noted that the EU is the biggest trade partner of all these three economies (UNCTAD, 2010).

To facilitate the agricultural trade with the EU the Moroccan monarchy follows a dual agricultural policy. On one side, the government facilitates the development of the export oriented farms, which are located on the most fertile part of the country. These agricultural elites are benefited by several programs (national and EU projects) which aim to the modernization of production and to harmonization of agricultural standards. On the other hand, substitute farmers are located on the less fertile parts of the country and they are excluded from any significant support and from the EU market. With this policy the state achieves two goals. The first is to control the big farmers by integrating them into the EU market. The second is to increase the revenues from agricultural production. At the same time, as the following Table 10 shows, the Moroccan (and the Egyptian) authorities try to prevent the imports of European dairy and meat products by supporting the domestic meat production. In 2008, the two countries imported many live animals in order to develop their production capabilities and tackle their deficit in meat and dairy goods (FAO, 2008). Yet, it is not certain that these measures will protect the local producers. According to the EC, from

Table 10. Live animals trade in the North African countries 2008.

\begin{tabular}{ccc}
\hline \multirow{2}{*}{ Country/Products } & \multicolumn{2}{c}{ Live animal trade thousands \$ } \\
\cline { 2 - 3 } Egypt & Exports & Imports \\
Morocco & 6,038 & 34,876 \\
\hline
\end{tabular}

Source: FAO. 
trade liberalization the non-competitive meat producers and the small-scale rain-fed agriculture in the partner countries will face the consequences of the ENP (European Commission, 2006).

The impact of the ENP Agreements is clear in sectors other than agriculture. The textile sector is still thriving in these countries, but the free trade agreements were signed in the 1980s, much earlier than the ENP, therefore this sector does not concern the present analysis. However, what is important to mention here is that industrial ventures in these countries, most notably in Morocco tend to concentrate in few industry subsectors (Bellin, 2002). In addition, the size of these companies is small as the cycle of their business. If someone counts the companies engaged in the informal sector then the average size of the North African companies is getting smaller. In addition, the vast majority of these companies is characterized by a low level of value added. In front of fears of further liberalization, the investment confidence has declined in the North African countries (Bellin, 2002). These fears are reinforced from econometric analyses, which, as mentioned above, show that the North African industrial sector will suffer from trade liberalization. However, the North African state has not supported adequately the domestic small and medium enterprises. To put it in a different way, it has supported the private sector industrialists, but in ways that do not contradict the logic of the market. One example of this logic is related to the procedures. For instance, in the past, the Egyptian state subsidized inputs to support the industries. Now, with funds provided by the EC, it has simplified the tax code and the procedures to open a new business (European Commission, 2010). According to the World Bank, in the two North African countries the average time and cost to start a business have decreased and they are below the average regional time and cost to start a business (IBRD/WB, 2010). In addition, the cost and time that are needed to export are below the regional average (IBRD/WB, 2010). Nevertheless, in front of the opposition from the small businessmen, the North African states liberalized their industrial markets slowly. As shown in Table 11, high tariffs remain in force. The decline of these illustrates the degree of protection in each North African state. These tariffs allow to the local entrepreneurs to be inefficient without losing their profits and the argument of the state is the same for the three countries. Rapid liberalization can create more problems than benefits.

Yet, it is not everyone that seeks protection from the state. From trade liberalization the energy sector and the other export oriented industries will gain more profits. Europe needs oil and gas, and as explained above, Russia is not the most

Table 11. Change in average scheduled tariff.

\begin{tabular}{ccccc}
\hline Country & Year & Average scheduled tariff & Year & Average scheduled tariff \\
\hline Egypt & 1995 & 24.30 & 2005 & 19.09 \\
Morocco & 1993 & 64.07 & 2006 & 15.53 \\
\hline
\end{tabular}

Source: UNCTAD 2008. 
reliable supplier. In Egypt, the local related elites are thriving from the trade with the EU. Morocco is not an oil exporting country, but there the Desertec projects are implemented. More specifically, the first Desertec project is constructed in Morocco and the biggest local conglomerate (Nareva) that takes part belongs to the royal family (Van Niekerk, 2010). So, in that case the political and the business elite are identical. Moreover, Morocco exports raw materials to Europe (especially phosphate) and in this case the related business elites share the same ideas with the Egyptian oil elites about free trade agreements.

These interests are not promoted in the same way as in Europe. The intention is not to glorify the European lobbying activities, which in many cases can be informal and exercised in dinner parties or other meetings. Yet, when compared to North Africa, in Europe the lobbying process is institutionalized, in other words, the related associations are independent and participate as advisors to workshops and to official seminars. In North Africa, lobbying on a collective basis is not the safest way for industrialists to promote their interests. As shown above, the operation of the related associations is compromised by the state. Bellin argues that for North African businessmen "individualistic lobbying offers them a surer route to shaping public policy” (Bellin, 2002). Actually, this means that the stature and the experience of the businessmen signify their success in lobbying their interests. Hence, the richest businessmen have easier access (formal or casual) to state elites and can pass their interests to the public officials. Especially, in Morocco this sort of activity is easier due to the small size of the country and of the business elite.

However, it would be a mistake to note that the approach of the two countries towards the EU is identical even if both of them have resisted reforming certain sectors. Especially regarding service reforms, Egypt was able to forestall reforms when compared with Morocco. This difference can be basically explained by the size of its economy and its natural resources. Morocco as smaller country, located in an economic space dominated by Europe, saw as a one way road the idea of having close trade links with the EU.

On the other hand, Egypt manages to have more flexibility against certain elements of the international agreements that has signed due to its revenues from oil exports and from the Suez Canal. In 2006/2007, the Suez revenues have increased by $17 \%$ and they form the $10.3 \%$ of the GDP (other types of transport are included in this percentage). Similarly, petroleum and mining (industries included) contribute $32.4 \%$ of the Egyptian GDP (African Economic Outlook, AfDB/OECD 2008: p. 274). According to the EC, the duties paid by vessels to the Egyptian authorities help to manage the trade deficit of the country (European Commission, 2010). Yet, slower reforms were not only an outcome of the increased state revenues from oil and the Suez Canal. An official working in the EU stated that the Egyptian authorities were reluctant to reform their economic structures because the domestic critics accused the government for undermining the economic independence of the country (Personal interview 13/12/2010). Yet, after 2008 the Egyptian authorities have been persuaded (and persuaded the 
domestic environment) that economic liberalization is the best development strategy that the country could follow.

\section{The Political Handling of the Domestic Environment}

The manipulation of the domestic economy was followed by managed liberalization in both countries. Due to external and domestic pressures, a piecemeal approach was followed at the political level. However, the pressures that the domestic and the international environment put on the ruling elites do not mean that these negotiated the rules of the game from a weak position. In both countries, the political elites took initiatives to broaden political participation, without losing control. In this respect, political liberalization worked as a safety valve, especially during periods of economic crisis. This valve was released when the government implemented hard economic policies and it achieved three aims. First, it changed the debate in the public sphere, second it weakened the opposition by partially satisfying the masses and third it satisfied the international actors.

The political elites controlled access to political offices and public sector jobs. As Bianchi notes the single party structures in North Africa provide the tools to these middle income countries to control crucial functions within and outside the state (Bianchi, 1989). Within these parties, a high degree of neo-patrimonialism characterizes their relations with the other actors, meaning that authority rests on personal power and that this power is under the control of the ruler. Usually, the power of the ruling elite is wielded through the powerful Ministries of the Interior. In both countries these ministries watch over directives related to every field, at the local or national level. They control which political parties can participate in the elections, how they can operate, their relations with international actors and the funding procedures. Mamdani described the work of the Sub-Saharan state and he concluded that while all the other ministries have specific functions, the Ministry of the Interior works like a state within a state, being the heart of the colonial state in Africa and the ministry for peasants (Mamdani, 2001). In the same way, Sorman explained the work of the government in Morocco. For him the economic problems of the country do not pertain to Islam, but to the system of governance, which resembles the feudal structures of the past (Sorman, 2005).

The ways that the top civil servants are hired provide a good example of these 'feudal' structures. In Morocco descendants of the well-known families that belong primarily to the conservative parties RNI and Istiqlal reach the top positions of the civil services in the country (Dawson, 2009). In Tunisia and in Egypt, even after the Arab spring of 2011, analysts acknowledge that the biggest challenge is to change the mechanism of the state, which remains basically the same and still represents Mubarak's party (Anonymous, 2011).

Yet, it is not only at the higher levels that the power of the political elites is reproduced. The structure of the state mechanisms is such that does not challenge the strength of the political elites. The civil service has the capacity to ab- 
sorb all these people of aristocratic, merchant and military origin. As stated above, the children of the well-known families reach the top political positions. At a different level, descendants of the merchandisers are used by the state for their commercial and managerial skills. According to the former minister of education in Morocco, they are necessary for the trade agreements with the EU. The military bureaucracy is used as an intermediate layer between the Palace and the various factions of the elite (Dawson, 2009). The internal stability of the system and the avoidance of any conflicts are achieved through marriages and religious orders. These traditional structures remain strong until today, even if the younger civil servants are distancing themselves from these orders.

This semi-feudal structure neutralizes any social or economic forces of development. In other words, any autonomous actions of the domestic groups are confined and the political systems in these countries are characterized by constellations of dependents to the head of the state (Sorman, 2005). The creation of these dependencies follows a similar historic pattern in these countries. When the King of Morocco, redistributed the land after the independence of the country, the best parts of it went to his clients and to the Palace. In Egypt, Nasser exercised a number of 'carrot and stick' policies to control labour unions. From one side, he created a number of laws to interfere in their internal affairs and a special agency within his party to control them. On the other hand, he gave them many privileges and monopoly status as a reward for their loyalty (Paczynska, 2009).

This situation has forced the opponents of the regime to operate underground and it has weakened NGOs, which do not concentrate support behind particular parties. This situation is most obvious in Egypt and it can help to explain the outcome of the revolts and the elections. During the Mubarak era, the Muslim Brotherhood had created a massive network of underground institutions to fill the gaps that the state could not fill. Simultaneously, by using a leftish rhetoric (dressed up with Islamic notes) since the left parties were excluded by the political arena, the MB was pushing for political reforms many years before the Arab Spring. In this sense, the Muslim Brotherhood was ready to occupy the space that was left after the end of Mubarak. At the same time, intellectuals were discussing potential reforms and certain elements of the Egyptian state were escaping from the domination of the executive. Some judges showed independent judgments in sensitive areas and the military (due to the pressures from the US) did not intervene much to prevent the revolts.

The reaction of the state to the increased support to the MS and to the small independent pockets that appeared in the Egyptian state was followed by a series of actions that froze any reforms. The regime postponed local elections in 2006, it extended the state emergency, it undermined judges' efforts to expand their independence, it cracked down several protests and it targeted high-ranking officials of the MS. Possibly, the worst reaction was related to the amendments of the constitution, in March 2007, which had an authoritarian content with the aim to restrict further the work of the MS. 
On the other hand, the work of the Moroccan state elites to control the frustration of the masses and the organization of the movements that were in favor of reforms was different. The King enjoys the divine power to rule the country and he cleverly has acted preemptively in order to mitigate the momentum of the protests. Under this perspective, the King proposed comprehensive constitutional changes aiming to reinforce the rule of law, to create an independent judiciary and a government that reflected the will of the people. These promises combined with the inexperience of the February 20 (2011) movement to organize structures that could produce more pressure to the regime eventually led to the weakening of the movement itself. The enthusiasm of the youth was followed by internal divisions and it did not go beyond sloganeering on social media sites. The monarchy allowed the demonstrations to go peacefully and unchallenged for two months, at which point it started to organize counter-demonstrations and when the tension had peaked, the King spoke on television (something that he rarely did) to introduce a draft constitution.

\section{Conclusion}

In general the political agenda has shifted from discussing democracy, onto talking about liberalization and, on many occasions, operational strategies. This has brought into light new forms of discursive politics. In turn, these are connected to who sets the agenda and under what circumstances and secondly, which are the alternative ways through which society can be organized so as to reduce inequality and enlarge democratic procedure and social justice. As in the beginning of this paper, we shall quote Wright once again, when he argues that we are left with “...a menu of strategic logics and an indeterminate prognosis for the future. The pessimistic view is that ... capitalism remains hegemonic ... the optimistic view is that we don't know what system challenges and transformative possibilities there will be in the future: interstitial strategies today can strengthen popular understandings that another world is possible and contribute to moving along some of the pathways of social empowerment" (Wright, 2010: p. 364).

\section{Acknowledgements}

Some of the ideas in this paper were presented at the $2^{\text {nd }}$ ISA Forum of Sociology in Buenos Aires, at the session dedicated to "Political Inequality outside of the West", on the 1st of August 2012. We wish to thank Professor Joshua Dubrow (Polish Academy of Sciences) for organizing the event and for the invitation.

\section{References}

Afouxenidis, A. (2012). The Role of Civil Society Organizations and of Informal Networks in Combating Discrimination. In D. Balourdos, \& A. Mouriki, (Eds.), Combating Discrimination in Greece (pp. 169-180). Athens: National Centre for Social Research.

Achy, L., \& Sekkat, K. (2010). Industrial Dynamics and Productivity in Morocco: A Quantitative Assessment. In K. Sekkat (Ed.), Market Dynamics and Productivity in 
Developing Countries (pp. 45-72). New York, NY: Springer. https://doi.org/10.1007/978-1-4419-1037-0_3

AfDB/OECD (2008). African Economic Outlook. Paris: OECD. http://www.oecd.org/dev/emea/africaneconomicoutlook2008.htm

Anonymous (2011). A Tricky Transition. Financial Times.

Beblawi, H. (1990). The Rentier State in the Arab World. In H. Beblawi, \& G. Luciani (Eds.), The Rentier State. New York, NY: University of California Press.

Bellin, E. R. (2002). Stalled Democracy: Capital, Labor and the Paradox of State-Sponsored Development. Ithaca, NY: Cornell University Press.

Benhaddou, A. (1997). Maroc, les élites du royaume: Essai sur l'organisation du pouvoir au Maroc. L'Harmattan.

Bensaad, A. (2007). The Mediterranean Divide and Its Echo in the Sahara: New Migratory Routes and New Barriers on the Path to the Mediterranean. In T. Fabre, \& P. Sant Casia (Eds.), Between Europe and the Mediterranean: The Challenge and the Fears (pp. 51-69). Hampshire: Palgrave Macmillan. https://doi.org/10.1057/9780230287334_5

Bianchi, R. (1989). Unruly Corporatism: Associational Life in Twentieth-Century Egypt. Oxford: Oxford University Press.

Bilgin, P. (2009). EU Security Policies towards the Mediterranean: The Ethical Dimension-What Do We Know and What Else Should We Know? INEX Policy Brief No. 2, December 2009 (Working Paper 6). Oslo: International Peace Research Institute. http://aei.pitt.edu/14991/

Bodenstein, T., \& Furness, M. (2009). Separating the Willing from the Able: Is the European Union's Mediterranean Policy Incentive Compatible? European Union Politics, 10, 381-401. https://doi.org/10.1177/1465116509337832

Comelli, M., \& Paciello, M.-C. (2007). A Cost/Benefit Analysis of the ENP for the EU's Southern Partners (Briefing Paper). European Parliament.

Dawson, C. (2009). EU Integration with North Africa: Trade Negotiations and Democracy Deficits in Morocco. London: Tauris Academic Studies.

Dillman, B. (2002). International Markets and Partial Economic Reforms in North Africa: What Impact on Democratization? Democratization, 9, 63-86. https://doi.org/10.1080/714000243

Emerson, M., Noutcheva, G., \& Popescu, N. (2007). European Neighbourhood Policy Two Years on: Time indeed for an "ENP plus" (Policy Brief No. 126). CEPS Policy Briefs. Brussels: Center for European Policy Studies.

European Commission (2006). Euro-Med Association Agreements: Agricultural Trade-Regional Impacts in the EU (Proceedings of the Workshop). Brussels: European Commission. http://ftp.jrc.es/pub/EURdoc/PB2006IPTS3548.pdf

European Commission (2010). Evaluation of European Commission's Support with Egypt-Country Level Evaluation. Brussels: European Commission. http://www.oecd.org/derec/ec/47240585.pdf

FAO (2008). Food and Agricultural Commodities Production. Rome: FAO. http://faostat.fao.org/site/339/default.aspx

Fontagné, L., \& Péridy, N. (1997). The EU and the Maghreb. Paris: OECD Publishing.

Fukuyama, F. (1992). The End of History and the Last Man. New York, NY: The Free Press.

Grabbe, H. (2003). Europeanization Goes East: Power and Uncertainty in the EU Accession Process. In K. Featherstone, \& C. Radaelli (Eds.), The Politics of Europeanization 
(pp. 309-310). Oxford: Oxford University Press. https://doi.org/10.1093/0199252092.003.0013

Grimson, A., \& Kessler, G. (2005). On Argentina and the Southern Cone: Neoliberalism and National Imaginations. London: Routledge.

Holm, U. (2008). North Africa: A Security Problem for Themselves, for the EU and for the US (DIIS Report No. 2). Copenhagen: Danish Institute for International Studies.

IBRD/WB (2010). Doing Business 2011: MENA Making a Difference for Entrepreneurs in the Middle East and North Africa. Washington DC: IBRD/World Bank.

IBRD/WB (2012). World Development Indicators 2012. Washington DC: IBRD/ World Bank.

Jaidi, L. (1994). La creation d'une zone de libre-echange entre l'Union europeenne et le Maroc: Motivations, attentes et constraints. Paris: CERCA.

Jelili, R., \& Goaied, M. (2010). Entry, Exit, and Productivity in Tunisian Manufacturing Industries. In K. Sekkat (Ed.), Market Dynamics and Productivity in Developing Countries (pp. 73-108). New York, NY: Springer. https://doi.org/10.1007/978-1-4419-1037-0_4

Mamdani, M. (2001). Beyond Settler and Native as Political Identities: Overcoming the Political Legacy of Colonialism. Comparative Studies in Society and History, 43, 651-664.

Paczynska, A. (2009). State, Labor, and the Transition to a Market Economy: Egypt, Poland, Mexico, and the Czech Republic. State College, PA: Pennsylvania State University.

Prebisch, R. (1950). The Economic Development of Latin America and Its Principal Problems. Lake Success, NY: United Nations Department of Economic Affairs.

Rapley, J. (2004). Globalization and Inequlaity: Neoliberalism's Downward Spiral. Boulder, CO: Lynne Rienner.

Ross, M. L. (2001). Does Oil Hinder Democracy? World Politics, 53, 325-361. https://doi.org/10.1353/wp.2001.0011

Sorman, G. (2005). Les Enfants de Rifaa: Musulmans et modernes. Paris: Le Livre de Poche.

Talani, L. S. (2009). From Egypt to Europe: Globalisation and Migration across the Mediterranean. London: Tauris Academic Studies.

Tangeaoui, S. (1993). Les entrepreneurs marocains: Pouvoir, société et modernité. Paris: KARTHALA Editions.

UNCTAD (2010). Handbook of Statistics 2010. New York, NY: United Nations.

Van Niekerk, S. (2010). Desertec: What Are the Implications for Africa? London: Public Services International Research Unit (PSIRU).

White, G. (2001). A Comparative Political Economy of Tunisia and Morocco: On the Outside of Europe Looking in. New York, NY: State University of New York Press.

Wright, E. O. (2010). Envisioning Real Utopias. London: Verso.

Zaiotti, R. (2007). Of Friends and Fences: Europe's Neighbourhood Policy and the "Gated Community Syndrome.” Journal of European Integration, 29, 143-162.

https://doi.org/10.1080/07036330701252581 
Submit or recommend next manuscript to SCIRP and we will provide best service for you:

Accepting pre-submission inquiries through Email, Facebook, LinkedIn, Twitter, etc. A wide selection of journals (inclusive of 9 subjects, more than 200 journals)

Providing 24-hour high-quality service

User-friendly online submission system

Fair and swift peer-review system

Efficient typesetting and proofreading procedure

Display of the result of downloads and visits, as well as the number of cited articles Maximum dissemination of your research work

Submit your manuscript at: http://papersubmission.scirp.org/

Or contact ojps@scirp.org 